Volume 2

Number 2 Popular Culture and Markets in

Turkey

Article 6

2017

\title{
Turkey at a Crossroads: The Political Economy of Turkey's Transformation
}

Turan Subaşat

Muğla Sıtkı Koçman Üniversitesi

Follow this and additional works at: https://digitalcommons.uri.edu/mgdr

Part of the Economics Commons, and the Political Science Commons

\section{Recommended Citation}

Subaşat, Turan (2017) "Turkey at a Crossroads: The Political Economy of Turkey's Transformation," Markets, Globalization \& Development Review. Vol. 2: No. 2, Article 6.

DOI: 10.23860/MGDR-2017-02-02-06

Available at: https://digitalcommons.uri.edu/mgdr/vol2/iss2/6

This Article is brought to you for free and open access by DigitalCommons@URI. It has been accepted for inclusion in Markets, Globalization \& Development Review by an authorized editor of DigitalCommons@URI. For more information, please contact digitalcommons-group@uri.edu. 
Turkey at a Crossroads: The Political Economy of Turkey's Transformation

\section{Markets, Globalization \& Development Review}
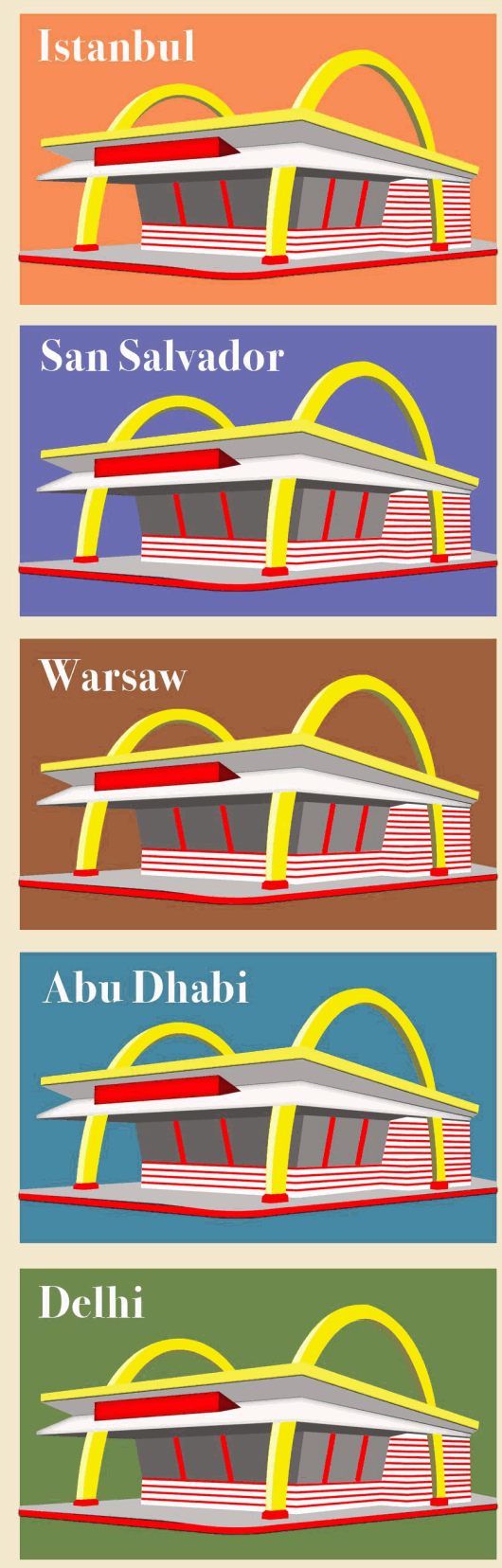
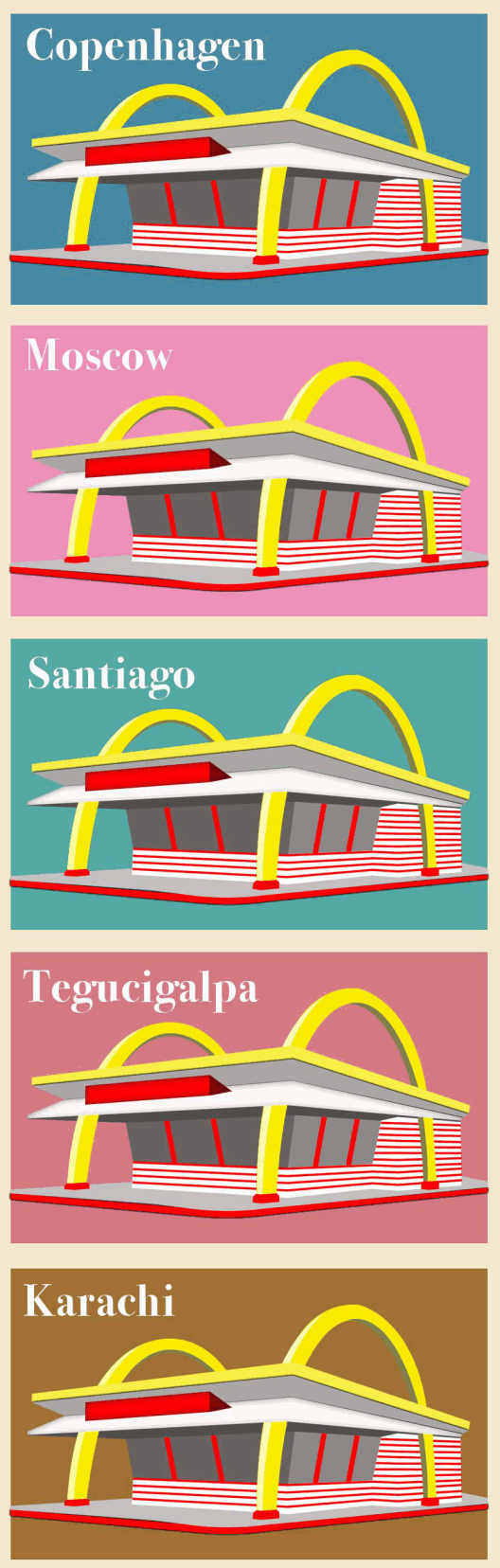
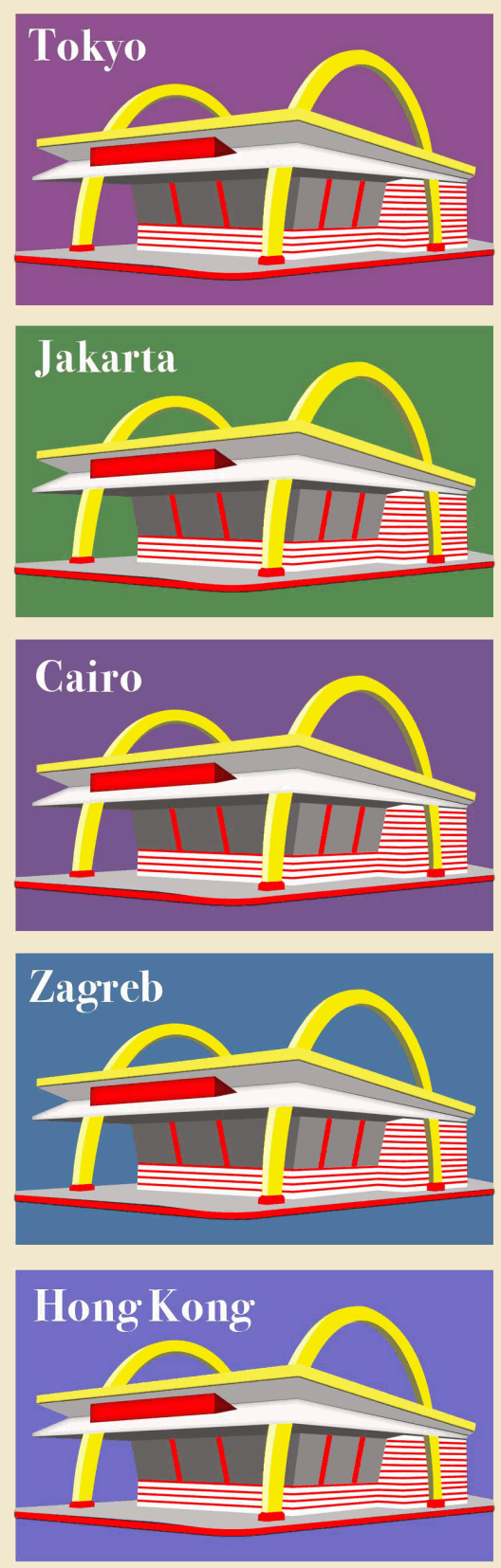

This article is available in Markets, Globalization \& Development Review: https://digitalcommons.uri.edu/mgdr/vol2/ 


\section{Turkey at a Crossroads: The Political Economy of Turkey's Transformation}

\section{Introduction}

Turkey is at a crossroads where politics overwhelmingly dominates economics. The country is prepared for a radical transformation and potentially a regime change. The new constitution affirms that some form of a regime change is imminent and while its nature is not yet obvious, it is likely to be authoritarian and less secular. The regime change had been planned long before the Islamist-oriented Justice and Development Party (identified by the Turkish initials AKP) came to power in 2002, but has accelerated rapidly since then. As early as 1994, Necmettin Erbakan (the former prime minister and a leading figure in Turkey's Islamic movement) said at the meeting of his Party's Parliamentary Group that "Refah Party will be elected and the justice system will be built. What is the remaining question? Will the transition period be tough or soft, bloody or bloodless?" (Salt 1999).

This paper argues that, although they may look contradictory at times, all the policies adopted by the AKP were designed to facilitate this transformation. Pragmatism is the keyword to describe the AKP governments. As will be explained in details below, the level of pragmatism often took extremely "contradictory" forms, which led them to be perceived as inconsistencies. The radical policy discrepancies before and after the 2011 election are an obvious example. Between 2002 and 2011, Turkey experienced considerable political and social progress. Democracy improved and initiatives for social peace accelerated. They were substantially reversed after 2011. Democracy deteriorated and the relative stability was replaced with political chaos.

Turkey's relationship with the neighbouring countries and the EU is another palpable example. Excellent relationships with the neighbouring countries under the "zero problems policy" were complemented with significant progress with the EU membership negotiations. Unfortunately, with the change of policies in 2011, the "zero problems policy" turned into a "zero friends policy" and the relationships with the EU deteriorated significantly.

Policy regarding the Kurdish population is another area where we have seen a dramatic shift. While the relationship between the AKP and the Kurdish citizens has had ups and downs through many years, the AKP had maintained close links with the Kurdish voters. But when a solution to the Kurdish problem was perceived as imminent in 2015, the peace process unexpectedly crumbled. The AKP formed an alliance with the far-right Nationalist Movement Party (identified by the 
Turkish initials MHP), which opposes any kind of deals with the Kurdish movement.

What explains these erratic policy reversals? The AKP supporters suggest that the AKP had to adopt temporary and mildly oppressive policies because it faced considerable hostility from the military and segments of the society with secular values. Additionally, they claim that the AKP had to respond to the changes in the external environment, which had become more hostile. Even for those supporters however, the AKP strayed too far from their original goals, and it was now time to get back to the "factory settings". These claims have proven inaccurate since the AKP became more authoritarian as it became more powerful.

This paper argues that there is no inconsistency between these seemingly contradictory policies. They complement each other to achieve a final objective: a regime change. The AKP needed the broadest political support to survive the above-mentioned hostility. The initial policies indeed brought together a vast section of the society and eased the concerns over secularism. The first period was designed to strengthen its powers in the face of many odds against the AKP. It was a period for developing and implementing both survival and defensive strategies.

Economic policies played a decisive role in this process. Policies were adopted to maintain strong support from the most vulnerable sections of the society. The poor experienced some improvements in their living standards through policies that boosted consumption. An illusion of economic miracle was also created. The economy appeared to grow rapidly while remaining resilient against internal and external shocks. While these policies were unsustainable in the long run, they were necessary in the short run to bolster the AKP's electoral appeal and to secure successive election victories.

The second phase can be called the transformation (or offensive) period. Once a strong government was secured and the threats were eliminated, it was time to move to the next stage where the process of regime change could begin. This stage inevitably required more authoritarianism since the fear of a regime change created strong opposition. Luckily for the AKP, however, almost all the strategic positions within the state apparatus were now under their control. Neither the military nor the people with secular values could pose a serious risk. This phase, however, witnessed lethal struggles within the AKP. The common survival instincts in the first phase united the different fractions in the AKP. Once the second phase started, however, struggles for more power within the party between former allies-turned-enemies - Erdoganists and Gulenists (who advocate alternative versions of Islam) - increased significantly. Internal struggles eventually turned into serious conflicts and led to the coup 
attempt in 2016 by the Gulenists. The 2016 coup attempt, which was later considered as a "gift from God" by the Erdoganists, turned into an "opportunity" and the subsequent state of emergency was used not only to eradicate the risks associated with the Gulenists but also employed to coerce a wide range of opponents. While the coup was a big blow for the Erdoganists in the AKP, now that the Gulenists were largely defeated, the transformation phase could continue as the Erdoganists wished.

Yet there was a time pressure on the Erdoganists since the "economic success" was built on weak fundamentals and was, therefore, unsustainable. A massive crisis or a perpetually low growth rates appear to be imminent: the signs are getting stronger. The relative sense of indulgence is likely to be replaced with a relative sense of indigence. Once this happens, the AKP's long lasting hegemony would be shaken and its long-term plans would be in jeopardy. For this reason, the AKP pressed for a radical constitutional change, pushing for a referendum under the state of emergency in an environment marked by social and political chaos that was undermining its legitimacy. Only a more authoritarian regime could rescue the AKP and allow it to achieve its long-term objectives.

Economics and politics are inextricably linked in all countries. This is particularly true for Turkey during the AKP period due to the above-mentioned transformation. An accurate understanding of the way in which the Turkish economy integrates into the global markets and the development pattern selected by the AKP will not be possible unless the broader political context is understood. Consequently, this article will first consider the political developments in Turkey since the AKP came to power. The following section, covers the AKP's radical policy discrepancies, which appear as inconsistencies at first glance but in effect complement each other in the face of dynamic political changes to achieve a regime change. The paper will then focus on the role of economic policies that were designed to create an artificial economic miracle and to stimulate short-term consumption to achieve successive election victories. The focus will be on how the miracle illusion was created through a number of creative policies and conjectural factors. Before concluding, the paper will discuss the presidential system, which is essential to seal what has been achieved and facilitate further and more radical transformations.

\section{Contradictions or Pragmatism}

Politics is a dynamic process where political actors frequently reorient themselves, sometimes surprisingly rapidly and radically. However, the level of the AKP's "pragmatism" is unprecedented in Turkish politics. Rapid and radical policy shifts, U-turns and the large gaps between the rhetoric and actual policies appeared as inconsistencies to many 
analysts. To give one illuminating example, on 29 November 2016, Erdogan said that the goal of Turkey's Operation Euphrates Shield in Syria was the overthrow of Assad. Just two days later, in the face of Russian reactions however, he said that his words should not be twisted, as the operation targeted no country or specific person but only terror organizations (Martel 2016). Both speeches were passionate enough to make one doubt what Erdogan actually said. Very often, Erdogan says something inconceivable and his supporters tell the public that what he means is, in fact, different. The AKP supporters respond to these inconsistencies by claiming that he is in the game of politics and such pragmatism is what makes him a great leader.

Such major and regular inconsistencies may lead to the perception that Turkey is led by incompetent leaders who are drunk with power and cannot decide on clear policy aims. This perception is wrong. It is not easy to make sense of the AKP policies unless the predominant objective is kept in mind: a regime change. The strength of the AKP lies in the belief that all policies are justified for the greater cause. The necessity of this level of pragmatism is well understood by its supporters. Challenged by the 17-25 December 2013 corruption allegations, for example, the supporters often concede the problems in private but they claim that they are not for personal interests but for the "cause".

This level of pragmatism is not unique to Erdoganists. Their former coalition partners, the Gulenists, also displayed masterful skills in this area. Fethullah Gulen's organisation concealed itself as a moderately religious charity. Gulen urged his followers to infiltrate the state and wait for the right time to rise up. To avoid the crackdowns in the army, the Gulenists officers "stocked their refrigerators with decoy bottles of alcohol and planted empties in the trash" and the Gulenist wives "started wearing bikinis more revealing than their hosts" at the pool parties (Filkins 2016). The Gulenists became more visible under the AKP rule but they remained invisible in strategic organisations such as the army. Although the Erdoganists claim that the Gulenists infiltrated into the state before the AKP came to power, no former governments planted them within the most important state apparatuses so openly and willingly. Indeed, Erdogan once said that he "gave them everything they wanted" (The Financial Times 2014).

The most important policy changes occurred after the 2011 elections. The policies were relatively progressive between 2002 and 2011 when significant economic, political and social improvements were achieved. In this period, the AKP formed coalitions with many segments of society. The AKP has been remarkably successful in terms of forming coalitions and breaking them apart once their objectives were achieved. The support from the liberal intelligentsia, 
who had hoped that the main objective of the AKP was to overcome the democratic deficits of the Kemalist regime, was particularly important to help to ease the fears of regime change. The liberals believed that the AKP would establish true democracy by removing the influence of the military over democratic institutions, introduce more freedom to the oppressed minorities, and resolve the gangrenous Kurdish issue.

Indeed, significant progress had been made on all fronts. The large portion of the population, including influential liberal intellectuals and external commentators, supported and praised these policies. The AKP won all the local and general elections and increased its lead, which is unique in Turkey's political history. Even the AKP's ideological opponents secretly admired this success.

These policies all changed rather abruptly from 2011 when the AKP received almost 50 percent of the votes. With an increased confidence, the AKP government became increasingly authoritarian which caused heightened public concerns and led to the Gezi Park protests in May 2013. The coalitions within the AKP started crumbling. The conflict between the Erdoganists and the Gulenists led to the major corruption allegations (led by the Gulenists) in December 2013. Erdoganists response to these two setbacks was to increase authoritarianism even further.

Here is a non-exhaustive list of policy switches that may at first appear as inconsistencies:

\section{Democratic reforms and basic rights}

Major democratic reforms were introduced within the first few years of the AKP government. The AKP started a campaign against torture and ill treatment, abolished the death penalty, adopted the European Convention of Human Rights, abolished the notorious Article 8 of the Anti-Terror Law which had been used for the imprisonment of journalists for crimes against Turkey's "unitary" structure, ratified the International Covenant of Civil and Political Rights and the International Covenant on Economic, Social and Cultural Rights, and abolished the State Security Courts (Bac 2005).

Press freedom improved considerably. According to the World Press Freedom Index by Reporters Without Borders (2016), Turkey was ranked $119^{\text {th }}$ out of 166 countries in $2003,98^{\text {th }}$ in 2005 and $99^{\text {th }}$ in 2008 that signifies a substantial improvement in a short period of time. The influence of the military over politics was brought under democratic control through a number of reforms (such as increasing the number of civilian members of the National Security Council and appointing a civilian as its Secretary General) and court cases were launched to determine the involvement of many high-ranking officers in a coup attempt against the government (Bac 2005). 
Reducing (or scrapping) the electoral threshold to create adequate room for small parties to secure state financing and parliamentary representation was considered. Radical reforms for the higher education were announced which included the abolishment of the Higher Education Board (identified by the Turkish initials YOK). YOK was established after the 1980 military coup and has been criticised for its over-centralised policies that curtailed academic freedoms. The proposed system would allow the University Senates to elect their rectors to ensure greater academic freedom and autonomy.

A series of democratic initiatives were launched and aimed at extending basic rights and freedoms of the citizens regardless of their ethnicity, religion, social class and political views. Some progress was made regarding religious freedoms. The restrictions on the use of the headscarf in public life were abolished and it was progressively allowed in schools and state institutions (including the army). There were a few gestures toward the other religious minorities. Alternative formulations to reopen the Halki Seminary (the Greek orthodox theological School that was closed down in 1971) were developed in 2004 and 2005.

Reforms for the Alevis (the largest religious minority in Turkey) were discussed and a legislation that would grant Cemevis (Alevi's places of worship) legal status was planned. Accordingly, the state would provide financial support to Cemevis and pay the salaries of Dedes (Alevi religious leaders). The AKP largely convinced the public that freedom of religion would be interpreted broadly in line with international norms and secularism was not under threat. Erdogan not only defended secularism in Turkey but also advocated it for the Arab world (Kuru 2013).

The ethnic reforms covered the Armenian, Roma and Kurdish initiatives. The Armenian initiative involved the restoration of an old Armenian church and allowing TV broadcasts in Armenian. The initiative also permitted a religious ceremony at the historical Armenian church after a 95-year hiatus. The Roma initiative addressed the widespread discrimination against the Romani people, and included an increased recognition of their identity and a boost in social programs to better integrate them into the society. The AKP also started the peace process with the Kurds, which deserves a separate section presented below.

After the 2011 elections, however, democratic reforms were reversed. Data from the Fraser Institute, Economist Intelligence Unit and the Freedom House (see Figure 1) all suggest that the key aspects of democratic life (judicial independence, impartial courts, integrity of the legal system, legal enforcement of contracts, reliability of police, electoral process and pluralism, functioning of government and civil liberties) improved within the first few years of the AKP government but then deteriorated significantly. Despite the numerous "wide-ranging" 
packages of political reforms unveiled by the AKP, these often remained as lip service to set the stage for upcoming elections and fell far short of expectations.

Figure 1: Changes in the quality of democratic institutions

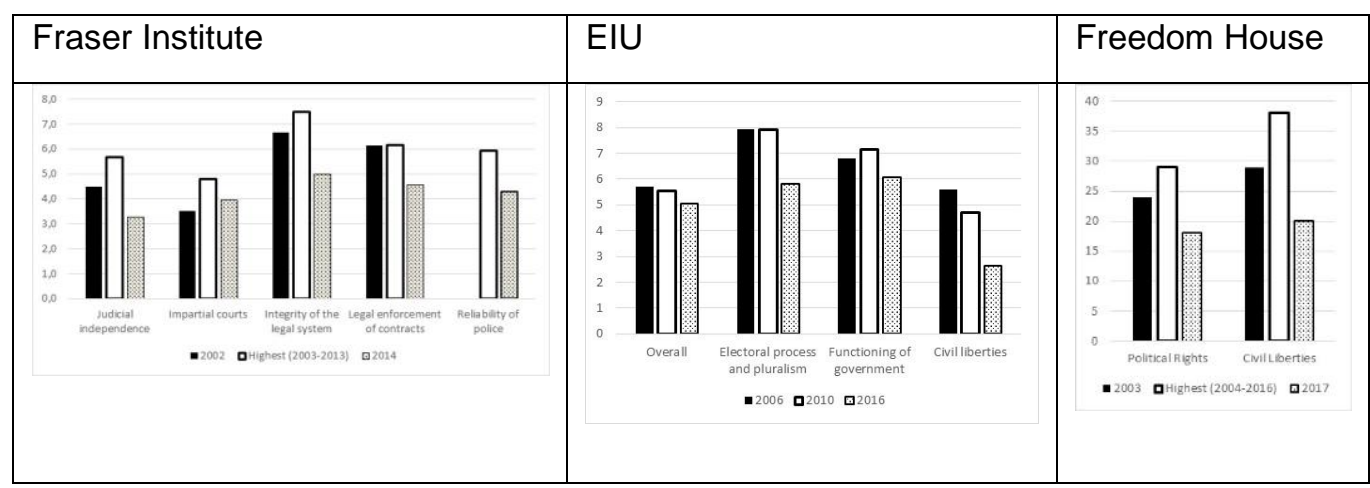

Sources: Fraser Institute, Economist Intelligence Unit and Freedom House.

Notes: A higher score denotes a better quality of institutions.

Fraser Institute: Fraser Institute's Economic Freedom of the World Index, EIU: Economist Intelligence Unit's Democracy Index, Freedom House: Freedom House's Freedom in the World Index.

Press freedoms also deteriorated significantly. Many journalists have been jailed, including the liberals who strongly supported the AKP in the past. In a letter written to their foreign ministry, Swedish newspaper editors argued that Turkey was now the world's biggest prison for journalists. A partisan media has been created and the opposition media has been suppressed. Dogan Media Group (the main media group in Turkey), for example, faced the largest ever tax penalty in Turkey's history in 2009 - a penalty that was politically motivated (Sozeri 2015). Many newspapers and TV channels have been shutdown over "terror propaganda". Turkey's rank in the World Press Freedom Index deteriorated rapidly from the $99^{\text {th }}$ in 2008 to $138^{\text {th }}$ in 2016 and $155^{\text {th }}$ in 2017. The Freedom House (2016) reported that

[Media] freedom in Turkey deteriorated at an alarming rate in 2015. The government (...) aggressively used the penal code, criminal defamation legislation, and the country's antiterrorism law to punish critical reporting, and journalists faced growing violence, harassment, and intimidation from both state and nonstate actors during the year. (...) The authorities continued to use financial and administrative leverage over media owners to influence coverage and silence dissent.

While the military's power over politics has been brought under democratic control, the court cases against the high-ranking officers 
(such as Ergenekon and Balyoz) were plots to eliminate the nonGulenist officers in the army which eventually resulted in the Gulenists led coup attempt in 2016. The Gulenists have been infiltrating the army since 1990s. They planted their members in the ranks by cheating on the entrance exams to the military schools and then removed the nonGulenists by torturing them under the banner of training.

Despite the earlier promise, higher education was not reformed and the YOK was not abolished. Up until recently, university rectors had been appointed by the president from a list of candidates who were selected by their university staff members and recommended by the YOK. When the AKP came to power, the former President Ahmet Necdet Sezer did not appoint the AKP adherents as rectors. Once Abdullah Gul became the president in 2007, however, (with the exception of few elite universities) all rectors were appointed from the AKP adherents and there were no more incentives to reform the higher education sector. After the coup attempt in 2016, rector elections were abolished and now the president appoints one of three candidates recommended by the YOK. The former AKP Prime Minister Ahmet Davutoglu once invited the Turkish academics around the world to come to Turkey and claimed that he was the guardian of their academic freedom. Since the coup, however, a large number of academics have been prosecuted, expelled from their posts and even jailed for "crimes" such as signing a petition.

The electoral threshold remains at ten percent and hinders the smaller parties. Erdogan recently said that the presidential system had long been his own personal project. Given that the presidential system is designed to give immense powers to the president and makes the parliamentary representation futile, the sincerity of the democratisation of the electoral system can be questioned.

The promise of religious freedom has largely been left unfulfilled. Halki Seminary remains closed and the Alevi reforms were not implemented. Religious freedom has been interpreted narrowly to support the dominant Sunni Islam. The Presidency of Religious Affairs insists that Alevis must use mosques as Cemevis cannot be recognised as alternative places of worship. Secularism is openly confronted within the AKP circles. The Parliament Speaker Ismail Kahraman, for example, said in April 2016 that Turkey's new constitution should drop all references to secularism and, as a Muslim country, Turkey should have a religious constitution. Those of the opinion that view secularism as atheism are gaining strength. In February 2012, Erdogan said he wanted to raise a religious youth, which is inconsistent with secularism. Thousands of new mosques have been built, the age limit on Qur'an courses has been abolished, enrolment to Imam-Hatip schools (which provide religious education 
and train Imams) has increased exponentially and compulsory religious education has been introduced.

\section{Kurdish issue}

The Kurdish initiative (or Kurdish peace process) was aimed at ending the protracted and violent conflict between the Turkish state and the Kurds by improving the political, social and economic rights of the Kurdish citizens. It created a positive atmosphere for the resolution of the problem, which covered a nearly 40-year conflict and cost over forty thousand lives. The release of the Democracy Party (Demokrasi Partisi) MPs in 2004, who had been in jail since 1994 for supporting Kurdish separatism, increased the credibility to the AKP government's claims about the implementation of the Kurdish reforms (Bac 2005). While the legitimacy of the government's secretive negotiations with the Kurdish group PKK was questioned widely, the de-escalation of the war and the possibility of a peace deal gained support from the majority of the population, which had been traumatised for decades. Despite the resistance from the military and the main opposition parties that had concerns regarding Turkey's "unitary" structure, Kurdish ethnic identity was explicitly recognised, and measures were introduced to permit the greater use of Kurdish languages and an official TV channel in Kurdish was established.

The relationship between the AKP and the Kurdish citizens, however, had an erratic pattern depending on the political conjuncture. The Kurdish issue has been instrumental for the AKP since it attracted a significant number of Kurdish votes. The AKP, therefore, considered reforms to resolve the issue as imperative. The government initiated secret negotiations with the Kurdistan Workers' Party (identified by the Turkish initials PKK) for a peace deal where the People's Democratic Party (identified by the Turkish initials HDP) played a facilitating role. The negotiations lasted for years and had ups and downs. Significant progress prior to elections was often followed by a period of deterioration, which revealed the functional role of the Kurdish issue for the AKP.

The violence was on hold for almost two years (between 2013 and 2015) and when a peace deal was seen as imminent, the "democratic initiative process" unexpectedly collapsed, the war with the PKK intensified and Turkey suffered a fierce circle of violence. The state of emergency (declared following the failed coup in 2016) targeted not only the Gulenists but also the Kurdish movement. The leaders of the HDP have been arrested and many civil servants (including teachers, judges and police) have been dismissed due to their alleged links to the PKK.

During the "democratic initiative process", the AKP had distanced itself from Turkish nationalism. Erdogan adopted remarkably 
strong language against nationalism. The alliance between the AKP and the MHP over the new constitution, therefore, signified an astonishing U-turn for both parties. While the details of the agreement between these two parties are unknown, a plausible explanation can be provided based on the AKP's presidential system ambitions, which will be investigated as a separate section below.

\section{External relations}

In the first few years of the AKP government, Turkey improved its relations with its neighbours under the "zero problems policy" and made rapid progress with its membership negotiations with the EU. Many believed that full membership to the EU was within reach. Significant progress was also made with the Cyprus problem. The Annan plan proposed a "United Republic of Cyprus" which would be a federation of two states. The plan, supported by the Turkish Cypriots, was rejected by the Greek Cypriots in 2004.

The AKP's neo-Ottomanism and desire to become the leading power in the region, however, largely backfired. The zero problems policy turned into zero friends (Zalewski 2013). Turkey had serious confrontations with Syria, Israel, Russia, Iran, Iraq and Greece. Turkey's involvements in Egypt and Syria, in particular, led to major problems with neighbours (Onis 2016). Eventually Turkey ended up without any allies in the region, which is termed by the former Prime Minister Davutoglu as a "dignified loneliness".

Relations with the EU soured significantly causing some EU member states to seek the suspension of further membership negotiations. The EU was a convenient security blanket for the AKP during the defensive phase. The hopes for the EU membership was the main reason for why the AKP avoided a shut down in 2008 when it faced charges for plotting an Islamic state. The EU had condemned the case and warned that the AKP's closure would damage Turkey's membership bid (Tait 2008). The EU was a crucial plea for keeping the military at bay since removing the AKP from power would jeopardise the EU membership. Moreover, the AKP's commitment to the EU not only signalled that the concerns over secularism were baseless but that the EU membership would also ensure secularism and democracy. While the EU's policies towards Turkey had not been trouble-free, the AKP's need for the EU's support declined substantially in the second phase and the EU membership requirements became a major obstacle to achieving its long-term objectives. The EU suddenly became an imperialistic block intervening in Turkey's domestic affairs. Even warnings against the introduction of the death penalty was considered as an unjustified intervention. It is now widely recognised that the "AKP used the EU reform process as an instrument of political survival" (Saatcioglu 2014, p. 86). 
To this day, no significant progress has been made over the Cyprus issue.

\section{The Role of Economy}

The economy has been the main strength of the AKP government in their first few years. Policies were designed to boost the economy in order to create a relative sense of economic wellbeing, which helped the AKP secure a series of election victories in the face of many internal and external shocks. Between 2002 and 2013, the annual average growth of nominal GDP was 12.2 percent, the nominal per capita GDP growth was 10.6 percent and the nominal exports growth was 12.4 percent (World Bank 2017). Inflation and budget deficit were brought under control. Despite large current account deficits and increasing external debt, the debt-to-GDP ratio remained low. The economy appeared to be resilient against internal and external shocks. The economy unremittingly grew between 2002 and 2008. While the nominal GDP declined from $\$ 730$ billion in 2008 to $\$ 614$ billion in 2009 due to the global crisis, it recovered rapidly and returned back to $\$ 731$ billion in 2010.

More importantly, poverty declined and the living conditions of the poor improved. The poverty headcount ratio - computed at the level of $\$ 3.10$ a day (2011 PPP) - declined from 9.94 percent in 2002 to 2.62 percent in 2013 (World Bank 2017).

The World Values Survey provides two useful household income survey results. First, the respondents were asked how satisfied they were with the financial situation of their household on a scale from one to ten. One indicates complete dissatisfaction and ten indicates complete satisfaction. I aggregate 1-5 (dissatisfied) and 6-10 (satisfied) levels to indicate the level of overall satisfaction. The figure $2 \mathrm{~A}$ shows that the percentage of the household satisfied with the financial situation was low in the first two survey waves (35 percent in 19891993 and 34 percent in 1994-1998) and declined further to 25 percent in the third wave (1999-2004). It then increased to 63 percent and 64 percent in the fourth (2005-2009) and fifth (2010-2014) waves, indicating a significant improvement in the satisfaction of households with their financial situation.

Second, the respondents were asked to place their household income (counting all wages, salaries, pensions and other incomes) on a subjective income scale, on which one indicates the lowest income group and ten indicates the highest income group in the country. The figure $2 \mathrm{~B}$ shows that respondents that place themselves within the poorest $10 \%$ substantially increased from the first wave $(4 \%)$ to the fourth wave $(22 \%)$ but radically declined to $2 \%$ in the fifth wave. In other words, only $2 \%$ of the respondents considered themselves within the poorest $10 \%$ of the income scale. The same figures for the 
respondents that place themselves within the poorest 30 percent were 34 percent in the first wave, 62 percent in the fourth wave and 14 percent in the fifth wave. While these are subjective indicators, they show a very strong improvement in the financial satisfaction of the poor sections of the society.

\section{Figure 2: Satisfaction of households with their financial situation}

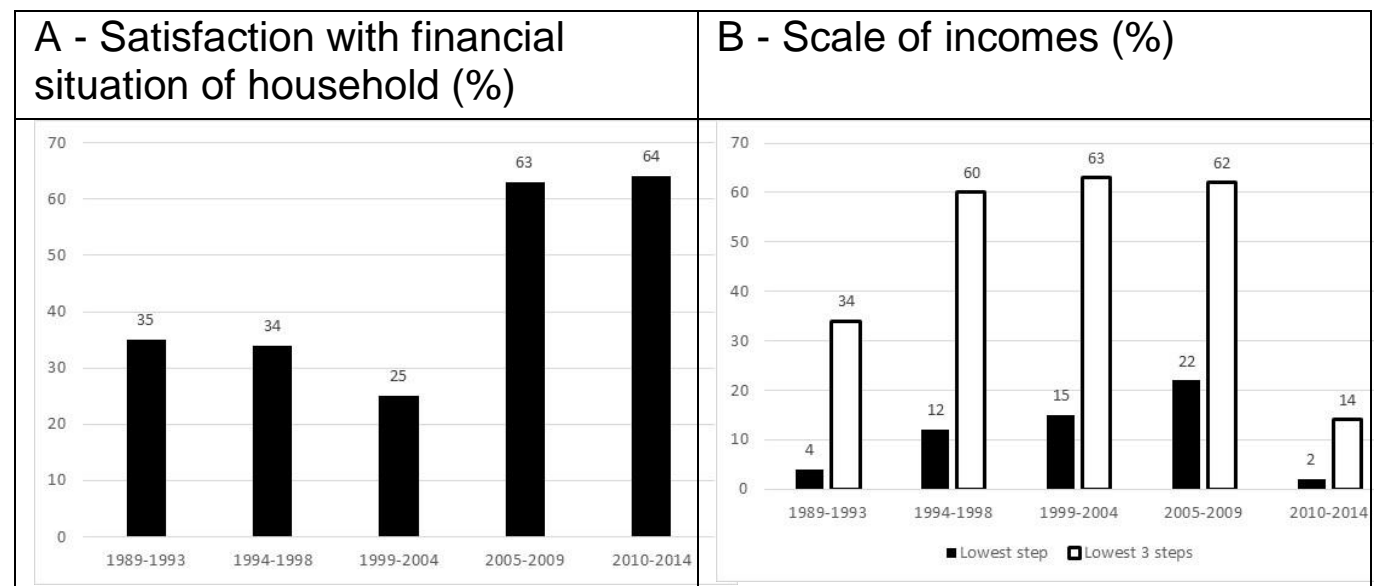

Source: World Values Survey

The economy was perceived to be the main strength of the AKP governments in the short and medium run but it turned out to be the main weakness in the longer run. Debt-driven growth is often unsustainable particularly if the external resources are used to stimulate consumption more than investment. Despite the above impressive growth figures, the economic success has been an illusion. The AKP adopted an economic strategy that boosted consumption to secure successive election victories. Turkey offered elevated real interest rates to attract substantial capital inflows (see figure 6) which caused overvalued exchange rates, mounting current account deficits, amplified external debt, and lower savings (imply higher consumption) and investment rates (Subasat 2014a).

The AKP supporters often argue that large capital inflows and high external debt are not a major source of concern since the debt to GDP ratio in Turkey remains stable. This argument is misleading since external debt excludes the liabilities and true risks associated with portfolio investment and foreign direct investment flows. In other words, external debt does not measure the true risks associated with total capital inflows. Figure 4 shows that the risk associated with capital inflows increased exponentially since the AKP came to power.

The saving rates were 20.2 percent of the GDP on average between 1990 and 2001, which declined to 15.9 percent between 2002 and 2015 (World Bank 2017). The same figures for the investment rates were 22.6 percent and 19.7 percent respectively. To put these 
figures in better perspective, it should be noted that the first period involved one international (1997 Asian crisis) and one domestic crisis (in 2001), and a major earthquake in 1999.

The economy became increasingly reliant in the construction sector, whose share in GDP increased from 4.5 percent in 2002 to 8.2 percent in 2015 (OECD 2017). The state played a significant role in this increase through urban regeneration plans, social housing programs and several mega projects (Eraydin and Kok 2014). While housing is a necessity, a construction led growth strategy is bound to stagnate since the construction sector is an import dependent sector that generates no exports.

The growth of nominal GDP, per capita GDP and exports were largely driven by the sharp decline in the value of the US dollar against all the major currencies (which was not unique to Turkey and similar trends were observed in most countries around the world) and the value gain of the Turkish Lira against the major currencies caused by the large capital inflows (Subasat 2014a). Once the artificial increase (due to exchange rate changes) is eliminated by using constant prices, however, the numbers look much less impressive. Figures 3A and 3B show that although GDP and exports in current prices increased substantially since 2002, no comparable increase is observed at constant prices.

\section{Figure 3: GDP and exports in current and constant prices in Turkey}

A: GDP (billions of dollars)

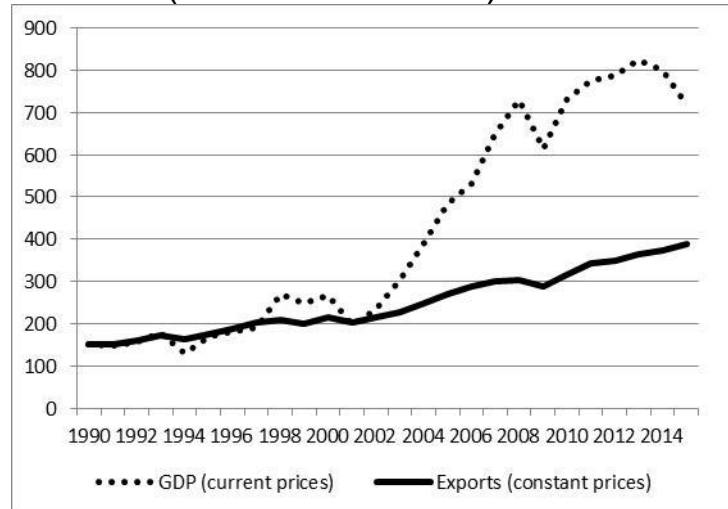

B: Exports (billions of dollars)

Source: World Development Indicators

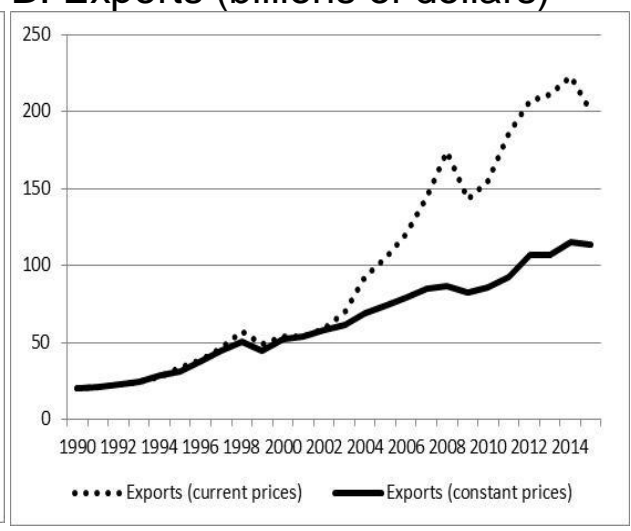

These figures look much less impressive once Turkey's performance is compared with the low, low-middle, high-middle and high-income country groups. According to Subasat (2014a), the Turkish economy grew faster than all the income groups between 1987 and 1999, then deteriorated substantially between 1999 and 2002 as a result of a devastating earthquake in 1999 and a major financial crisis 
in 2001. Despite attracting considerable external financial resources between 2002 and 2011, however, Turkey's economic growth had been moderate and remained below that of the middle and low-income country groups. Turkey only grew faster than the high-income countries that experienced one of the worst economic crises in their history. Despite substantial capital inflows, therefore, the economic growth rates have been disappointing. Unlike the common perceptions, the export performance significantly deteriorated during the AKP period. Turkey was more successful than all the income groups between 1987 and 1999, and less successful throughout the AKP period. The overvalued currency reduced the growth of real exports whereas the real import growth rates remained stable, resulting in large trade and current account deficits.

While poverty declined in Turkey between 2002 and 2013, this was not unique to Turkey and most low and middle-income countries experienced similar trends. In fact, the decline in poverty looks less impressive when it is compared with other countries. Turkey was ranked $38^{\text {th }}$ out of 56 countries in terms of the speed of poverty decline within the same period (World Bank 2017).

Despite the government's widespread propaganda regarding production of national tanks, aircraft, ships and satellite projects, by 2023, the share of investment in GDP declined and high-tech exports remain very low. Turkey was ranked $101^{\text {st }}$ in the world in terms of the share of high-tech exports in 2002 and was ranked $107^{\text {th }}$ in 2014 (World Bank 2017).

The risks associated with excessive external borrowing have increased significantly since the AKP came to power. Heavy reliance on external financial resources creates significant risks but the risks are greater if the resources are used to support unproductive activities such as consumption and non-exports sectors. We have already seen that in Turkey the share of investment in GDP, export growth rates and domestic savings declined considerably since 2002 and the share of consumption increased. This implies that the external financial resources have been used to increase consumption rather than investment and exports. Uysal and Subasat (2016) developed an index to capture such risks. Figure 4 shows that the risks associated with external financial resources remained low between 1990 and 2003, and increased radically from 2004 . The risk in 2014 is ten times higher than what it was in 2003.

The cumulative real house prices, price-to-income ratios and price-to-rent ratios - which increased significantly preceding the 2008 housing market crash - are often used to assess a housing bubble. Turkey was ranked $3^{\text {rd }}$ out of 23 countries in terms of cumulative real house price changes between December 2010 and July 2016 (IMF $2017 \mathrm{a}), 2^{\text {nd }}$ out of 32 countries in terms of price-to-income ratio 
(Cushman \& Wakefield 2016) in 2016 and $1^{\text {st }}$ out of 36 countries in terms of price-to-rent ratio in 2016 (IMF 2017b).

\section{Figure 4: External debt risk index}

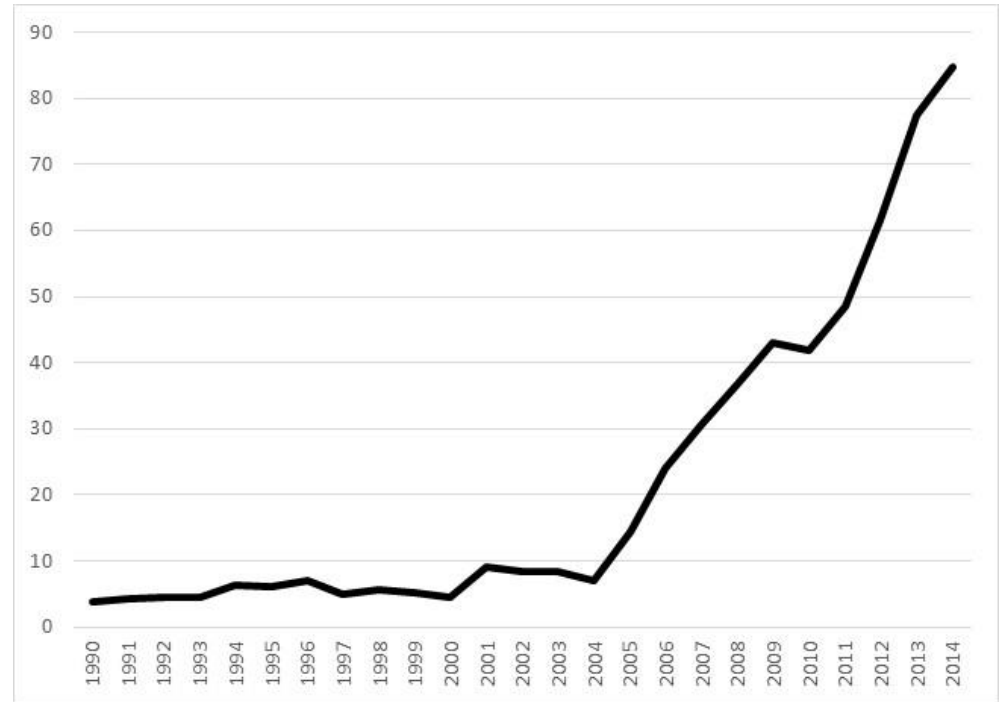

Source: Uysal and Subasat (2016)

Comparing housing prices in Turkey and the countries that recently experienced housing bubbles would provide useful information but Turkey has housing price data only since 2010. Buyukduman (2014), however, calculated an average price index for Istanbul since 1998, which allows us to compare housing price changes in Istanbul with New York and London. Figures 5A and 5B show that Istanbul experienced a bubble comparable to both cities. The bubble (from boom to slump) covers the 1996-2008 period for London and the 19962008 period for New York.

The rapid real price increases started in 2002 in Istanbul and still continues. Figure 5A shows that the average annual price increase for the bubble period for Istanbul (2002-2016) has been higher than both London (1996-2008) and New York (1997-2006). Figure 5B shows that since the beginning of the bubble in Istanbul in 2002, the housing prices increased by 380 percent. The same figure for London was 290 percent and for New York 210 percent before they experienced their crises. In other words, the average housing prices increased more quickly and for a longer time period in Istanbul than in London and New York. While Istanbul has not yet experienced a collapse of the bubble, the developments are worrying and a collapse appears to be imminent. 
Figure 5: Housing prices in Istanbul, New York and London

\begin{tabular}{|l|l|l|}
\hline $\begin{array}{l}\text { A: Average annual growth of } \\
\text { housing prices } \\
\text { (\% real prices) }\end{array}$ & $\begin{array}{l}\text { B: Increase in housing prices } \\
\text { between the beginning and the } \\
\text { end of the bubbles } \\
\text { (\% real prices) }\end{array}$ \\
\hline 12,0 & & \\
\hline 10,0 \\
8,0
\end{tabular}

Sources: Buyukduman (2014) for Istanbul, Freddie Mac (2017) for New York and Office for National Statistics (2017) for London. I would like to thank Dr Buyukduman for providing me with the latest housing price data for Istanbul.

There are now signs that "Turkey's economic miracle" might be rapidly coming to an end. The worsening external environment implies that the global liquidity is now drying up and Federal Reserve's interest rate increases are likely to cause massive problems for countries that build their economies based on large capital inflows. Turkey's GDP (in nominal dollars) contracted since 2013, Turkish Lira lost more than 30 percent of its value against the dollar between September 2016 and January 2017 and unemployment increased rapidly from 8.7 percent in 2013 to 11.6 percent in 2016 (Turkish Statistical Institute 2017). The credit rating agencies (Moody's, S\&P and Fitch) all reduced Turkey's credit ratings in 2016. The Consumer confidence index declined from 93.5 in 2004 to 65.7 in (February) 2017 (Turkish Statistical Institute 2017). These signs hint at either an approaching crisis or slower economic performance for a considerable period.

\section{The causes of economic success illusion}

The economic success in Turkey was an illusion and the following few points played a key role in its creation.

First, as we discussed above, the AKP adopted an economic policy to boost consumption without enhancing production. This was possible due to the massive capital inflows (see the capital account in figure $6 \mathrm{~A}$ ), which were facilitated by the rapid increase in global liquidity during the 2000s. These capital inflows were supplemented by the substantial privatisation policies and real estate sales to foreigners. 
Second, apart from the official capital inflows, Turkey received substantial unofficial external resources. The net error and omissions (NEO) of the balance of payments, which measures such unofficial capital flows, have increased considerably during the AKP period (see figure 6B). The cumulative NEO was negative between the 1975-2002 period indicating net unofficial capital outflows. Since 2002, however, cumulatively it increased to $\$ 41.7$ billion in 2016 , indicating substantial unofficial capital inflows. A notable feature of the unofficial inflows is that they substantially increased during the election years. Figure $6 \mathrm{~B}$ shows that the NEO increased substantially in 2003, right after the AKP came to power in November 2002. Another notable increase was in 2011, which was an election year. The NEO increased to record levels in 2015, when there were two general elections as well as in 2016, a particularly difficult year due to the deteriorating economy and escalated political and social tensions. In fact, 51 percent of the unofficial capital inflows took place in 2015 and 2016; 70.9 percent in 2011, 2015 and 2016; and 81.7 percent in 2003, 2011, 2015 and 2016; indicating that these flows were politically motivated.

These figures are substantial but Subasat (2017) argued that the official NEO figures are just the tip of the iceberg. By using the official balance of payments statistics and the data on household foreign currency holdings, the actual unofficial capital inflows were estimated to be at least $\$ 110$ billion. To put this figure in context, note that the total reserves of the Turkish Central Bank were $\$ 106$ billion in December 2016. At present, we do not know who sent these resources to Turkey, how they did it, and for what specific purpose they have been used. It is not difficult to presume, however, that the resilience of the economy against various internal and external shocks and the relative satisfaction of lower income households with their financial situation can be linked to these capital inflows.

Figure 6: Turkey's Balance of Payments

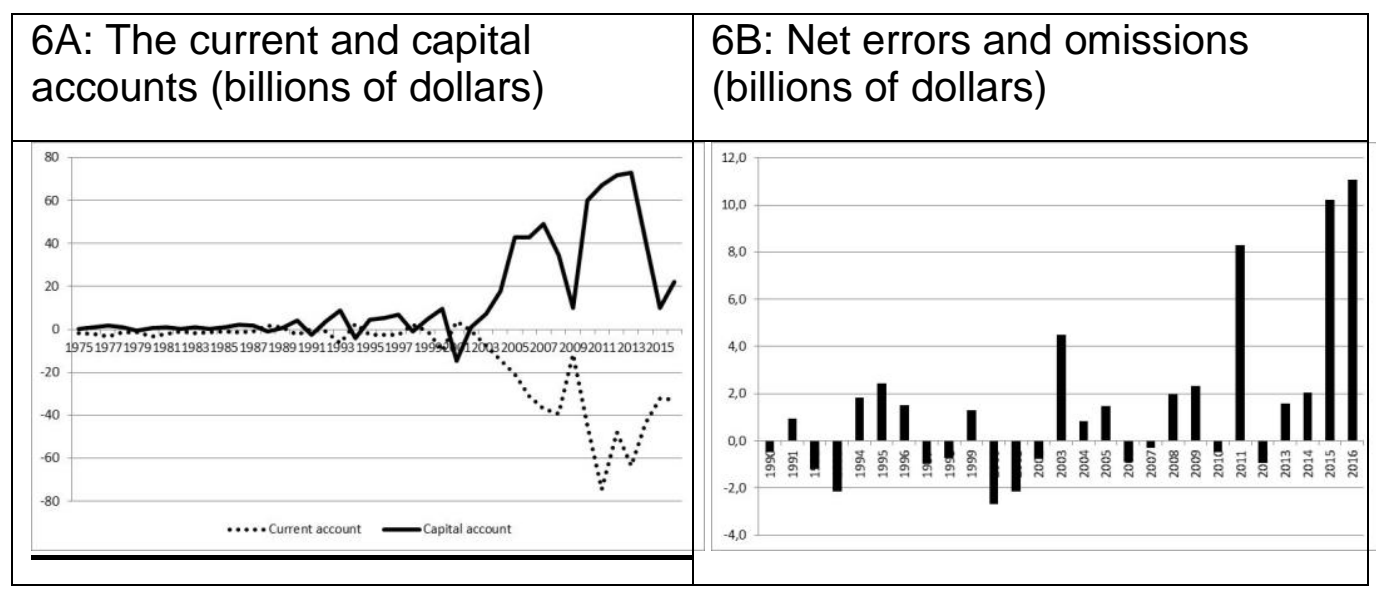

Source: Turkish Statistical Institute (2017) 
Third, the overvalued exchange rates (caused by capital inflows) also created a false sense of positive wealth effect by artificially cheapening imported goods. Households' welfare increased faster than their sustainable income, which increased their satisfaction as well as their support for the AKP.

Fourth, while there has not been a notable improvement in income distribution (Sonmez 2013), the living conditions of the poor improved significantly through the transformation of welfare policies. The rights based welfare system was not abandoned but a charity based welfare system was developed to achieve two main objectives: the Islamisation of the country and gaining the support of the poorest sections of the society. The direct social assistance schemes were expanded rapidly (Esen 2014). Various types of aid to the poor covered a wide range of areas: health, food, fuel, shelter, clothing, education, old age, caring for elderly, widowhood, etc. More than 13 million people are estimated to have benefited from these assistance schemes. In 2015, a total of 25.8 billion Turkish Lira worth of social assistance (1.33 percent of the GDP) provided over 600 Turkish Lira each month to poor households, a sum large enough to more than double the average monthly income (Aile ve Sosyal Politikalar Bakanlığı 2015). While this level of support for the poorest section of the society should normally be considered admirable, the direct social assistance policies often became a propaganda tool, and had a strong impact on the voting patterns of the poor. The Housing Development Administration not only contributed directly to the construction-led economic growth in Turkey but also helped the low and middle-income households by providing them with affordable housing.

Fifth, the propaganda over the tripling of the GDP since 2002 worked well and boosted the AKP's popularity, even though no comparable income increase was experienced by individual households. This could be explained partially by Hirschman's "tunnel parable" which claims that people initially tolerate their poverty because the improved income of the others creates expectations to catch up in the near future. The tunnel effect can be explained by the following example:

Imagine you are driving in a two lane tunnel with both lanes headed in the same direction. All traffic is jammed as far as you can see - which is not very far. Suddenly the lane next to you starts to move. Initially you feel better, even though you are still stuck, because this signals to you that the jam has ended and your own lane will soon start moving too (Muthoo 2013).

The rapid economic growth myth, therefore, may have transmitted a positive signal to the poor and middle-income households in Turkey. 
Sixth, the five-year time period before the AKP came to power (1997-2001) had been the most difficult time period for Turkey, with two crises (one international in 1997 and one domestic in 2001) and a massive earthquake in 1999. This overlapped with vicious political disputes, high inflation rates and excessive levels of government debt. The late 1990s had been etched in the memory of the population as an extremely difficult period. The early AKP years, on the contrary, were considered as very auspicious due to low inflation, balanced public budget, (the illusory) high economic growth, political stability, the EU membership prospects and political initiatives (particularly over the Kurdish issue). The new rhetoric and faces in politics provided comfort and a glimmer of hope for the overwhelmed population.

Seventh, the relatively low impact of the 2008 crisis on the Turkish economy (especially compared to its neighbouring European countries such as Greece), reinforced the AKP's image of economic success. Indeed, the GDP contracted by 4.82 percent in 2009 but recovered quickly and increased back to its 2008 level in 2010. Turkey's banking sector had been significantly reformed after the crisis of 2000-2001, which contributed to the resilience of the economy. A stroke of good luck also played a significant role as the global toxic financial instruments were not injected into Turkey's underdeveloped financial system (Icke et al. 2011). The strength of the banking sector turned the 2008 crisis into a short-term opportunity as Turkey was perceived as a safe haven for the international capital.

Eight, China's entry into the World Trade Organization (WTO) in 2001 caused a significant decline in the prices of investment and consumer goods. The decline in prices helped to control inflation and led to a significant rise in prosperity, primarily by increasing the purchasing power of the poor. The AKP came to power one year after China's entry into the WTO and took advantage of this positive wealth effect.

Ninth, both fear mongering and hope mongering have been used extensively. After any major political and economic setback, the AKP raises the issue of internal and external enemies who are trying to stop Turkey's enviable economic progress. An "upper wisdom" has become a convenient enemy to unite the nation around the government. While the "upper wisdom" is never properly defined, it comprises a widespread group of people, institutions and countries that may include - depending on the conjuncture - the Gulenists, the USA, the EU, the UK, Germany, France, Israel, Russia, the United Arab Emirates, Iran, Saudi Arabia; Armenian, Jewish and interest rate lobbies; global financial capital and the credit rating agencies. Accordingly, these enemies are responsible for the Gezi Park protests, the corruption allegations in 2013, the 2016 coup attempt, terrorism, 
high interest rates, the depreciation of the Turkish Lira and any other problems that Turkey faces.

Interestingly, while Turkey offered the highest levels of real interest rates in the world since the AKP came to power to attract more external resources, the "interest rate lobby" was conveniently used as a scapegoat for the high interest rates. Although, Erdogan advocates low interest rates and often confronts the Turkish Central Bank to achieve this objective, the Turkish economy has become so dependent on capital inflows to finance its current account deficits that attempts to lower the interest rates cause capital outflows and actually end up raising the interest rates again. Calling for lower interest rates also conflicts with the election rhetoric of the AKP that claimed that Turkey experienced lower interest rates since the AKP came to power. Indeed, the nominal interest rates have been lower due to lower inflation rates but the real interest rates have been amongst the highest in the world (See Subasat 2014a).

After the Turkish Lira lost significant value against the US dollar between October 2016 and January 2017, the government claimed that the economy was fundamentally healthy and this was purely a malicious speculative attack against the Turkish economy. The government claimed further that those who participated in this assault were no different from terrorists and that the credit rating agencies (Moody's, Fitch and Standard and Poor's) were their collaborators. The credit rating agencies had increased Tukey's credit rating four or five times since the AKP came to power but reducing the credit rating just once (in the face of clear political and economic risks) was sufficient enough to declare these agencies as traitors.

The AKP's list of terrorists and their collaborators include the electors who voted no in the April 2017 constitutional referendum, Organisation for Security and Co-operation in Europe (for raising doubts about the fairness of the referendum), some US politicians, bureaucrats and academics. The list included Preet Bharara (The US Attorney for the Southern District of New York) who oversaw the arrest of Reza Zarrab. Zarrab was arrested by Bharara in 2016 for conspiring to evade U.S. sanctions against Iran but he was also involved in the 2013 corruption allegations in Turkey.

The "2023 targets" are a good example for hope mongering, which have been used to foster a sense of false hope. The most important of these targets is to enter into the top ten largest economies of the world. None of the long-term global growth projections (conducted by Goldman Sachs, HSBC, PricewaterhouseCoopers, OECD, CEIP, CEPII and IMF), however, placed Turkey within the first ten largest countries by 2023 (Subasat 2014b).

Currently the tenth largest country is Canada with a GDP that is 2.15 times larger than Turkey's. To surpass Canada, Turkey's nominal 
GDP must grow 10.13 percent faster each year than Canada by 2023, which is clearly unrealistic. Moreover, the long-term global growth projections are notoriously difficult and there are reasons to think that Turkey may even fall behind its current rank. As we argued earlier, the Turkish economy grew based on foreign capital inflows that artificially inflated the economy since 2003. Because such growth is unsustainable, Turkey will inevitably face slower economic growth once capital inflows subside.

Tenth, Turkey is a good example of the "authoritarian neoliberalism", which may have increased the resilience of the economy against shocks. According to Bruff (2014, p. 113), "we are witnessing the rise of authoritarian neoliberalism, which is rooted in the reconfiguring of the state into a less democratic entity through constitutional and legal changes that seek to insulate it from social and political conflict". Similarly, Onis (2016, p. 142) suggests that

[a]mong the basic ideas behind this trend is the notion that capitalist development does not require liberal democracy. Instead, [...] such development may be achieved in a minimally democratic environment based on competitive elections and a narrowly construed majoritarianism that pushes aside such principles as respect for the rule of law, safeguards for minority rights, and reverence for civil liberties.

Accordingly, not only did the government create its own crony businesses, which are conveniently used during difficult times, but also the large businesses are frequently intimidated to act in certain ways the government wishes. According to "the crony-capitalism index" constructed by The Economist (2017), Turkey was ranked $12^{\text {th }}$ out of 22 countries in 2014, which increased to $8^{\text {th }}$ in 2016. Irak (2015, p. 15) argues that "the political structure in Turkey during the AKP period mostly relied on a pan-Islamist crony capitalism based on the party's own economic and social networks". According to Bugra and Savaskan (2014), AKP used invitations rather than open bidding for public projects, which proves that the AKP government used the state initiatives to create its own crony capitalism (See also Gurakar 2016). In addition, the government told businesses to employ more workers and organize campaigns to encourage households to sell dollars.

Finally, rapidly evolving technologies have led to the confounding of the concepts of "success" and "prosperity". Rapid technological developments cheapened infrastructural works such as building roads, tunnels and bridges - works that were expensive in the past. The prosperity increases due to rapid technological developments have been perceived as the success of the government, which has given priority to particularly visible and high-profile projects. Double roads, shopping malls and "crazy projects" created profitable 
opportunities for the crony businesses and defrauded the public. The tunnel effect may also be relevant here. While these projects are largely irrelevant for the needs of the poor, a general prosperity increase creates the hopes that it would trickle down to them eventually. Such projects also nurture the national pride and make people feel good about their own lives.

\section{Presidential System}

The increased authoritarianism, corruption allegations (which have yet to be investigated) and the establishment of a de facto presidential system (that was inconsistent with the constitution) broke the coalitions that the AKP had established with wide segments of society. These developments brought together the women's organisations, the youth, professionals, trade unions, left wing organizations, Kurdish activists and the Alevis who were galvanized during the Gezi Park protests in 2013 (Monroe 2017). The intensified conflict between the Erdoganists and Gulenists, the worsening relations with the EU and regional countries, and the deterioration in the economy forced the Erdoganists into a defensive position. To resolve these self-made problems, the presidential system was pushed on to the agenda and abolishing the parliamentary system became the number one priority of the AKP.

Falling from power is not an option for the AKP. Not only would this terminate their regime change desires but it would force many AKP members to face legal charges. The June 2015 elections were a chilling warning that time was running out and the AKP needed to act swiftly. The AKP started propagating the "Turkish style presidential system" which signified an immensely powerful presidential system (hyper-presidentialism) via lessening the separation of powers (legislative, executive and judicial) leaving it without accountability. The Economist (2017) suggests "Turkey's new constitution goes too far. The country would end up with a 21 st-century sultan minimally curbed by parliament. A Yes would condemn Turkey to the elected dictatorship of President Erdogan".

The AKP claims that only a strong presidential system (by ruling out the possibility of coalition governments) could generate political stability and achieve rapid economic development. As The Economist (2017) rightly argues, however...

... [this] kind of stability is hollow. The most successful democracies make a point of separating powers and slowing governments down [...] Turkey is especially ill-suited to winnertakes-all government. It is divided between secular, religious and nationalist citizens, as well as Turks, Kurds, Alevis and a few remaining Greeks, Armenians and Jews. If the religiousconservative near-majority try to shut out everyone else, just as they were once shut out, Turkey will never be stable. 
The empirical evidence also does not support the AKP claims. On the contrary, in terms of economic stability and growth, the parliamentary systems and coalition governments have been proven to be more successful than presidential systems and single party governments (McManus and Ozkan 2016; Nooruddin 2011; Subasat 2013). The recent experiences in Turkey are a testimony to the failures of one-party system. The AKP has formed single party governments since 2002 and a de facto presidential system since 2014. Apart from the first few years of their governance, however, there has been neither political stability nor economic success.

To form a presidential system, the AKP initiated the Constitutional Reconciliation Commission, which was established in 2011 with the participation of all four major parties represented in the parliament. The stated aim of the Commission was to reform the 1982 constitution, which carried the characteristics of the military regime (Kentel, Koker and Genc 2012). The AKP's insistence on a presidential system, however, caused this initiative to fail. This was the main reason why the AKP radically changed its Kurdish policy.

The peace process increased the HDP's votes rather than the AKP's. The HDP's progressive rhetoric over workers' rights, gender, environment and social justice won the hearts and minds of the people who were disillusioned with the increased AKP authoritarianism. The HDP won 13.1 percent of the votes in June 2015 and became the third biggest party in the parliament. The AKP's votes declined from 49.83 percent in 2011 to 40.87 percent. It became obvious that the HDP would not support the AKP with its presidential system ambitions in exchange for a peace deal. "We will not make you the president" was the motto of the HDP in the June 2015 elections. The Kurdish movement had become a major barrier for the regime change.

For a regime change, the AKP required the support of either of the minor opposition parties (MHP and HDP) that were antagonistic to each other. Now that the HDP was unwilling to support the regime change, the AKP had no option but to play the nationalism card and approach to the MHP. Erdogan, who in 2013 famously said "we are a government that has trampled on all kinds of nationalism" and created furious reaction from the MHP, now adopted a nationalist rhetoric and the MHP, a party that had always been openly opposed to the presidential system, initiated the 2017 presidential referendum. The MHP was willing to support the AKP with its presidential system ambitions in exchange for an anti-Kurdish policy.

The two-year peace process broke down rapidly. The pressure from the Western allies to play an active role in the coalition against ISIS was used "as an occasion to attack the PKK as part of the allaround campaign against terror groups" (Onis 2016, p. 150). A bomb attack, which took place two days before the June 2015 general 
elections in the HDP meeting in Diyarbakır, signalled the end of the peace process. There had not been a major terrorist attack since 11 May 2013, which had killed 52 people in Reyhanli. Two more major attacks by ISIS took place leading up to the second general election in November 2015. On 20 July 2015, a bomb killed 34 young left wing activists in Sanlıurfa and 103 people were killed at the peace meeting in Ankara on the 10 October 2015. Turkey conducted the November 2015 elections under these circumstances.

The failure of the opposition parties to form a coalition government led to the general election in November 2015. The uncompromising position of the MHP was responsible for this failure. The Republican People's Party (identified by the Turkish initials CHP the main opposition party in Turkey) even offered the Prime Minister position to the MHP leader Bahceli, which was rejected with some harsh words. The AKP claimed that only it could establish stability again, which was considered by the opposition parties as a blackmail tactic. The AKP's motto in the elections was "vote for the AKP for stability and security". The politics of fear helped the AKP (Onis 2016), which came back to power as a single-party government. "Pluralism and freedom of expression had moved down on the list of public concerns" (Onis 2016, p. 150).

Turkey witnessed a vicious circle of violence in 2016 as The Kurdistan Freedom Hawks (TAK - a breakaway fraction of the PKK) responded to the ISIS bombings. According to Onis (2016, p. $150)$, the PKK "played into the AKP's hands by unwisely assuming that major powers would back a renewed push for an independent Kurdish state as a reward for Kurdish help against ISIS". More than twenty terrorist attacks by TAK and ISIS killed over 300 people. This chaos was followed by the military coup attempt on 15 July 2016 . The nature of this coup is still debated. While the government claims that it was organised by the Gulenists, the opposition parties (CHP and HDP) claim that this was a controlled coup attempt implying that the government was aware of the coup attempt in advance but allowed it to strengthen its position. Whoever is right about the nature of the coup attempt, it is clear from the following developments that it was a blessing for the AKP and was used as a pretext to oppress a wide range of opposition movements that disproportionately affected the Kurds.

The Economist (2017) claims that since the failed coup, the government has demonstrated how cruelly power could be abused under a state of emergency. According to the magazine...

... [roughly] 50,000 people have been arrested; 100,000 more have been sacked. Only a fraction of them were involved in the coup. Anyone Mr Erdogan sees as a threat is vulnerable: 
ordinary folk who went to a Gülenist school or saved with a Gülenist bank; academics, journalists and politicians who betray any sympathy for the Kurdish cause; anybody, including children, who mocks the president on social media (The Economist 2017).

The 15 April 2017 constitutional referendum took place under these circumstances. The state of emergency, one-sided media coverage and the lack of equal opportunities created an uneven playing field; and the electoral fraud allegations put the legitimacy of the constitutional referendum into question.

\section{Conclusions}

This paper argues that Turkey is going through a (counter) revolution. The adoption of the new constitution is not the end but a milestone on the way to establish the above-mentioned regime change. By equipping the president with immense powers, the new constitution opens avenues for further and more radical transformations.

The AKP insists that Turkey is not turning into an authoritarian regime. According to the Deputy Prime Minister Mehmet Simsek, the April 2017 referendum was not to begin a regime change. Turkey is still a democracy with a secular state, which is run by the rule of law and dedicated to universal values, fundamental rights and freedoms (Camlibel 2017). The developments in Turkey over the last few years, however, strongly contradict these claims.

To summarize, the AKP had a very promising start in 2002. All aspects of economic, political and social life witnessed significant improvements and the AKP received substantial domestic and international support. The AKP had the unusual opportunity to form the most powerful single-party government in Turkey's recent history. Many commentators naïvely, in this author's view, considered the AKP as one of the centre-right parties that have dominated Turkish politics since 1950. They were therefore surprised that it did not suffer from governmental fatigue, a familiar feature of Western democracies (Onis 2016). Ersel (2013, p. 21) claimed, for example, that the...

... founders of AKP were sincere about their intentions and wanted to establish AKP as a party of masses, and not a party solely for the deeply religious groups in the society. Their emphasis was strongly on human rights, democracy and in favor of "free" market system. In contrast to its predecessors, the $\mathrm{AKP}$, at least initially, was careful not to be identified as antiWestern.

Regrettably, however, the AKP failed to fulfil its promises. Over time, the AKP became more authoritarian as it became more powerful. "The courts, the police, the intelligence services, the mosques, the 
public education and health systems and the media are all, in one way or another, subject to the party's overweening influence" (The Economist, 2017). Some commentators claimed that the AKP was poisoned by its own powers and became a victim of its own success (Hale and Ozbudun 2010). It was time for the AKP to get back to its "factory settings". This interpretation was naïve. As The Economist (2016) reports...

... [Early] in his career Mr Erdogan made a telling remark he was later to regret. Democracy is like a train, he said; you get off once you have reached your destination. Now many of his party's critics fear that Turkey's president may be getting close to that goal.

The constitutional process provides us with important clues regarding what the AKP is trying to achieve. The new constitution was drafted by the AKP and MHP. It lacked a broader political consensus and involved no consultation from universities and NGOs. The constitutional referendum took place during the state of emergency under which democratic rights had been suspended and when the leaders of the third largest party, many journalists, and thousands of people had been jailed. The referendum process lacked equal opportunities, was reported on by one-sided media coverage, and was fraught with electoral fraud allegations. It was approved only by 51.4 percent of the population, which is very low for a constitutional change that ought to be based on a broad social consensus. While all the above points put the legitimacy of the constitutional referendum into question, the AKP shows no sign of remorse. Given that the AKP had already established a de facto presidential system and that there is no reason to think that the new constitution is likely to resolve any of the problems Turkey faces, one important question remains to be answered: Why did the AKP rush through the new constitution despite the fact that the process lacked legitimacy? This paper argued that there is only one plausible explanation. Only an authoritarian regime could save the AKP.

The AKP planned a regime change and acted accordingly. A regime change, however, is never an easy process. It is a nonlinear one that entails ups and downs, swings and fluctuations. In order to survive the defensive phase, the AKP adopted seemingly progressive policies to secure the support from wide sections of the society. It created an illusory economic "miracle" based on unsustainable policies, which helped to get the broad support it needed. The AKP has been remarkably successful in managing public opinion through propagandist techniques - a good example of manipulative marketing at a macro level. Little successes were exaggerated and major problems were underplayed. The AKP propaganda regarding the 
economic success was mirrored in the writings of many liberal minded intellectuals who kept on repeating the same falderal of the decline in the illiteracy rate, the increase in urban population, increase in the total length of highways and roads (see for example Ersel 2013).

Once it strengthened its powers and removed the threats, the AKP started the second phase where a regime change could begin. The AKP reacted to the rapidly changing environment pragmatically. What are sometimes observed as policy inconsistencies were in fact the AKP's reactions to the changing environment in these two periods. The second phase required more authoritarianism since the fear of a regime change created a stronger opposition. The coalitions that the AKP had established collapsed one after another and the Kurdish issue became unsustainable. This phase also witnessed serious conflicts within the AKP and reactions from the outside world including the EU. The unsustainable economic policies had also reached their limits. An approaching economic crisis could mark the end of the "economic miracle."

The above points imply that the time was running out for the AKP. A wide array of opponents are eager for an opportunity to topple the AKP; their situation is now like riding a bike: it will fall if it stops pedalling. The June 2015 election results and the July 2016 military coup attempt implied that only a more authoritarian regime could save the AKP. Erdogan already acted like a president but needed extra powers, which would make it next to impossible to remove him. 


\section{References}

Aile ve Sosyal Politikalar Bakanlığı (2015), "Aile ve Sosyal Politikalar Bakanlığı 2015 Yılı İdare Faaliyet Raporu", Ankara, (accessed April $21 \quad 2017$ ), [available at http://www.aile.gov.tr/data/56d469a8369dc56f90d98bbd/2015\% 20Y\%C4\%B11\%C4\%B1\%20Bakanl\%C4\%B1k\%20\%C4\%B0dar e\%20Faaliyet\%20Raporu.pdf].

Bac, Meltem Müftüler (2005), "Turkey's Political Reforms and the Impact of the European Union", South European Society \& Politics, 10 (1), 16-30.

Bruff, Ian (2014), "The Rise of Authoritarian Neoliberalism", Rethinking Marxism, 26 (1), 113-29.

Bugra, Ayse and Osman Savaskan (2014), New capitalism in Turkey: the relationship between politics, religion and business. Edward Elgar, Cheltenham, UK; Northampton, MA, USA.

Buyukduman, Ahmet (2014), Bir Kent Efsanesi Konut Balonu. Scala Yayıncılık, Istanbul.

Camlibel, Cansu (2017), "Turkey is not turning into an authoritarian regime: Deputy PM to Western companies", Hurriyet Daily News, April/22/2017, (accessed April 24, 2017), [available at http://www.hurriyetdailynews.com/turkey-is-not-turning-into-anauthoritarian-regime-deputy-pm-to-westerncompanies.aspx?pagelD=238\&nID=112285\&NewsCat ID=345].

Cushman \& Wakefield (2016), "Türkiye Konut Sektörü: Konut Balonu", Cushman \& Wakefield Araştırma Yayını, İkinci Yayım.

Dholakia, Nikhilesh (2011) "Finanzkapital in the twenty-first century", Critical perspectives on international business, 7 (1), 90-108.

Eraydin, Ayda and Tuna Tasan-Kok (2014), "State Response to Contemporary Urban Movements in Turkey: A Critical Overview of State Entrepreneurialism and Authoritarian Interventions", Antipode, 46 (1), 110-29.

Ersel, Hasan (2013), Politico-economic development of Turkey and the transformation of political Islam, The Economic Research Forum Working Paper 746, (accessed April 22, 2017) [available at https://erf.org.eg/wp-content/uploads/2014/03/746.pdf].

Esen, Bunyamin (2014), "Myths and facts about Turkey's welfare regime", Daily Sabah, (accessed April 22, 2017), [available at https://www.dailysabah.com/opinion/2014/08/26/myths-andfacts-about-turkeys-welfare-regime]. 
Filkins, Dexter (2016), "Turkey's thirty-year coup: Did an exiled cleric try to overthrow Erdoğan's government?", The New Yorker, 17 October 2016, (accessed April 24, 2017), [available at http://www.newyorker.com/magazine/2016/10/17/turkeys-thirtyyear-coup].

Fraser Institute (2017), "Economic Freedom of the World 2014", (accessed April 25, 2017), [available at https://www.fraserinstitute.org/].

Freddie Mac (2017), "House Price Index", (accessed April 25, 2017), [available at http://www.freddiemac.com/finance/house price index.html].

Gurakar, Esra Ceviker (2016), Politics of favoritism in public procurement in Turkey: Reconfigurations of Dependency Networks in the AKP Era. Palgrave Macmillan: New York.

Hale, William and Ergun Ozbudun (2010), Islamism, Democracy and Liberalism in Turkey: The Case of the AKP. Routledge: London and New York.

Icke, Basak Turan, Esra Nemli Caliskan, Yusuf Ayturk and Mehmet Akif Icke (2011), "An Empirical Research of Ethical Banking in Turkey", Journal of Modern Accounting and Auditing, 7 (3), 289304.

IMF (2017a), "Turkey: Selected Issues", IMF Country Report No. 17/33.

IMF (2017b), "The Global Housing Watch", (accessed April 27, 2017), [available at http://www.imf.org/external/research/housing].

Irak, Daghan (2015), "Reading political clientelism and concentration through new media: The case of Anadolu Agency", in Yeni Medya Calişmalari III, E. Saka, A. Sayan and V. Görgülü, eds. Taş Mektep Yayınları: Istanbul.

Kentel, Ferhat, Levent Koker and Ozge Genc (2012), "Making of a New Constitution in Turkey Monitoring Report: October 2011 January 2012", Turkish Economic and Social Studies Foundation, (accessed April 25, 2017), [available at http://tesev.org.tr/wpcontent/uploads/2015/11/Monitoring Report Making Of A Ne w Constitution In Turkey October 2011 January 2012.pdf].

Kuru, Ahmet T. (2013), "Muslim Politics Without an 'Islamic' State: Can Turkey's Justice and Development Party Be a Model for Arab Islamists?" Policy Briefing, Brookings Doha Center Publications. February 2013. 
Martel, Frances (2016), "After Accusing Assad of 'State Terror,' Erdogan Says Troops in Syria Only Targeting 'Terror'”, Breitbart News (1 December 2016), (accessed April 22, 2017), [available at $\quad$ http://www.breitbart.com/jerusalem/2016/12/01/turkeyerdogan-flip-flops-overthrowing-assad/].

Ozkan, Fatma Gulcin and Richard McManus (2016), Who does better for the economy? Presidents versus parliamentary democracies. University of York.

Monroe, John (2017), "Why did Turkey's regime turn to the iron fist?", Socialist Worker, (accessed April 26, 2017), [available at https://socialistworker.org/2017/01/11/why-did-turkeys-regimeturn-to-the-iron-fist].

Muthoo, Abhinay (2013), "The Tunnel Effect", (accessed April 21, 2017), [available at http://www2.warwick.ac.uk/fac/soc/economics/news/2013/4/tunn eleffect/].

Nooruddin, Irfan (2011), Coalition Politics and Economic Development: Credibility and the Strength of Weak Governments, Cambridge University Press: New York.

OECD (2017), OECD.Stat (database), (accessed April 25, 2017).

Office for National Statistics (2017), "House Price Index", (accessed April 27, 2017), [available at https://www.gov.uk/government/collections/uk-house-priceindex-reports].

Onis, Ziya (2016), "Turkey's Two Elections: The AKP Comes Back", Journal of Democracy, 27 (2), 141-54.

Reporters Without Borders (ed.) (2016), "World Press Freedom Index", Paris, (accessed April 26, 2017), [available at https://rsf.org/en/ranking].

Saatçioğlu, Beken (2014), AKP's 'Europeanization' in Civilianization, Rule of Law and Fundamental Freedoms: The Primacy of Domestic Politics, Journal of Balkan and Near Eastern Studies, 16 (1), 86-101.

Salt, Jeremy (1999), "Turkey's Military Democracy", Current History, No 98.

Sonmez, Mustafa (2013), "TÜiK, bu yalanı, araştırma diye satma artık", (accesed April 20, 2017), [available at http://mustafasonmez.net/?p=3666].

Sozeri, Ceren (2015), Media Ownership and Control: journalists, owners find themselves increasingly dominated, in Press 
Freedom in Turkey's Inter-Election Period, International Press Institute, S. M. Ellis, ed. (accessed April 25, 2017), [available at https://ipi.media/wp-content/uploads/2015/10/IPI Turkey InterElection Press Freedom Report - Final.pdf].

Subasat, Turan (2013), “Koalisyon Hükümeti Türkiye’yi Çökertir Miti”, Iktisat ve Toplum, 37.

Subasat, Turan (2014a), "The political economy of Turkey's economic miracle", The Journal of Balkan and Near Eastern Studies, 16 (2), 137-60.

Subasat, Turan (2014b), “Umut Tacirliği, Kriz ve Türkiye'nin 2023 Hedefleri Miti", Iktisat ve Toplum, 40.

Subasat, Turan (2017), “Türkiye'ye Kayıt Dışı Sermaye Girişlerinin Gerçek Boyutları", Iktisat ve Toplum, 76.

Tait, Robert (2008), "Turkey's governing party avoids being shut down for anti-secularism", The Guardian, (accessed April 20, 2017), [available

at https://www.theguardian.com/world/2008/jul/30/turkey.nato1].

The Economist (2016), "Getting off the train", (accessed April 25, 2017), [available at http://www.economist.com/news/specialreport/21689877-mr-erdogans-commitment-democracy-seemsbe-fading-getting-train].

The Economist (2017), "Turkey's Referendum: Turkey is sliding into dictatorship", (accessed April 26, 2017), [available at http://www.economist.com/news/leaders/21720590-recep-

tayyip-erdogan-carrying-out-harshest-crackdown-decades-westmust-not-abandon].

The Economist Intelligence Unit (2017), "Democracy Index", (accessed April 26, 2017), [available at https://infographics.economist.com/2017/Democracylndex/].

The Economist (2017), "The crony-capitalism index", (accessed April 26, 2017), [available at http://www.economist.com/blogs/graphicdetail/2016/05/dailychart-2].

The Financial Times (2014), "Turkey: The Erdogan-Gulen showdown", (18 March 2014), (accessed April 12, 2017), [available at https://www.ft.com/content/1b1d4ea0-ab8e-11e3-8cae00144feab7de].

The Freedom House (2016), "Country report on Turkey", (accessed April 12, 2017), [available at https://freedomhouse.org/report/freedom-press/2016/turkey]. 
The Freedom House (2017), "Freedom in the World Index", (accessed April 27, 2017), [available at www.freedomhouse.org/].

Turkish Statistical Institute (2017), "Main Statistics", (accessed April 27, 2017), [available at http://www.turkstat.gov.tr].

Uysal, Soner and Turan Subasat (2016), "Cari Açıkların Sürdürülebilirliği," Iktisat ve Toplum, 65.

World Bank (2017), World Development Indicators, Washington, DC: World Bank, (accessed April 13, 2017).

Zalewski, Piotr (2013), "How Turkey Went From 'Zero Problems' to Zero Friends", Foreign Policy, (accessed April, 25 2017), [available at http://foreignpolicy.com/2013/08/22/how-turkeywent-from-zero-problems-to-zero-friends/]. 